\title{
Productive performance, blood biochemical variables and immune responses of laying hens fed diets containing various fat sources
}

\author{
S. Abbasi, J. Fakhraei ${ }^{\#}$ H.M. Yarahamdi \& S. Khaghani \\ ${ }^{1}$ Department of Animal Science, Arak Branch, Islamic Azad University, Arak, Iran
}

(Received 2 October 2018; Accepted 5 March 2019; First published online 26 July 2019)

\author{
Copyright resides with the authors in terms of the Creative Commons Attribution 4.0 South African License. \\ See: http://creativecommons.org/licenses/by/4.0/za \\ Condition of use: The user may copy, distribute, transmit and adapt the work, but must recognize the authors and \\ the South African Journal of Animal Science.
}

\begin{abstract}
This study was conducted to evaluate the effects of various fat sources on productive performance, blood biochemical variables and immune responses of laying hens. Laying hens were divided into seven groups, which received i) basal or control diet (no oil); ii) and iii) basal diets containing $1 \%$ and $3 \%$ soybean (SB) oil; iv) and v) basal diets containing $1 \%$ and $3 \%$ kilka oil (KO), and vi) and vii) basal diets containing $1 \%$ and $3 \%$ soybean fatty acids (SFA). Productive performance was evaluated from day 1 to day 84. Blood biochemical variables and immune responses were assessed on days 28, 56 and 84 of the trial. The study results indicated that the dietary inclusion of $1 \%$ and $3 \% \mathrm{KO}$ and SFA and $3 \%$ SB oil could decrease the feed conversion ratio (FCR) and increase egg production and egg mass in comparison with the control group throughout the study. Immune responses of sheep red blood cells and antibody titre against hemagglutination inhibition $(\mathrm{HI})$ were significantly higher in laying hens fed $\mathrm{KO}$ and SFA and 3\% SB oil compared with the control group. The serum concentrations of low density lipoprotein-C (LDL-C), very low density lipoprotein-C (VLDL-C) and malondialdehyde (MDA) were not influenced by the inclusion of oil sources. The serum concentration of cholesterol was increased significantly in laying hens that were treated with oil on day 28. The inclusion of fat sources significantly increased the serum concentration of HDL-C. The use of KO and SFA could be recommended at lower levels to improve the performance, immunity and some blood variables in laying hens.
\end{abstract}

Keywords: egg production, kilka fish oil, lipid profile, soybean oil

\# Corresponding author: j-fakhraei@iau-arak.ac.ir

\section{Introduction}

Oils and fats are concentrated sources of energy that are essential for improving the composition of diets and maintaining the energy/protein balance (Rowghani et al., 2007; Oliveira et al., 2009). The inclusion of fat sources in the diet of laying hens increased the energy density of the diet and metabolic energy efficiency, modified the fatty acid profile of the egg yolk, and improved palatability and feed conversion ratio (FCR) (de Oliveira et al., 2011). Animals can synthesize saturated and monounsaturated fatty acids, but cannot synthesize linoleic acid and linolenic acid (Lehninger et al., 2002). Nobakht et al. (2011) reported that the inclusion of lipids in the diets of laying hens increased energy density, metabolic energy efficiency and palatability. The oil sources contain long chain polyunsaturated fatty acids (PUFAs), which change the lipid profile in the egg yolk (Eseceli \& Kahraman 2004; Skrtic et al., 2008). Several fatty acid sources have been used in poultry diets, including linseed (flax), soybean (SB), sunflower and fish oils. Soybean products are known as essential protein and energy sources in poultry feeds. Soybean oil is rich in lysine, tryptophan, isoleucine, valine and threonine amino acids (Larbier \& Leclercq, 1994) and linoleic acid (Jalali et al., 2015). Full-fat SB is a good source not only of protein, but also of energy, and can be used in swine and poultry diets (Lichovnikova et al., 2013). Stunted growth and immunity have been reported in diets that are deficient in fatty acids (Farhoomand \& Chekani-Azar, 2009). The inclusion of linseed oil in diets of laying hens could have beneficial effects owing to its unsaturated fatty acids, that is, C18:3. The supplementation of sunflower 
oil increases levels of C20:4 in the egg yolk (Schreiner et al., 2004; Pita et al., 2006). Wu et al. (2005) reported that the inclusion of fat could significantly improve the FCR in laying hens compared with the control. Fats improve immune responses by increasing lymphocyte proliferation and antibody production (Fritsche et al., 1991). The inclusion of fatty acid sources in animal nutrition not only enriches the contents of n-3 PUFAs in the diet (Pietras \& Orczewska-Dudek, 2013; Yanovych et al., 2013; Zdunczyk \& Jankowski, 2013), but also modulates immune system activity (Kew et al., 2003). Saki et al. (2016) showed that the inclusion of oxidized oil did not have significant effects on high density lipoprotein-C (HDL-C), low density lipoprotein-C (LDL-C) or very low density lipoprotein-C (VLDL-C). Ding et al. (2017) reported that the inclusion of essential fatty acids could improve the FCR and egg production in laying hens. Zaki et al. (2018) showed that the use of SB oil sources could decrease lipid oxidation in the meat of broiler chicks. Bozkurt et al. (2012) reported that diet supplementation of essential fatty acids did not have significant effects on the productive performance in laying hens. Fish oil is a fishery sub-product that can be used instead of SB oil in poultry diets (Seidavi \& Simoes, 2015). Fish oil can be replaced with SB oil in diets only at low levels to minimize its adverse effects on the sensory attributes of meat broiler chicks (Bou et al., 2004) and improve immune responses (Al-Khalifa et al., 2012). Seidavi et al. (2014) did no observe effects of dietary fish oil on the immune response of broiler chicks challenged with various antigens. Alparslan \& Ozdogan (2006) advised the use of fish oil (2\%) to improve feed cost efficiency and preserve the performance and healthiness of broiler chicks. To the best of the authors' knowledge, no study has compared various fat sources in the diet of laying hens on performance, immunity and blood parameters. Thus, this study aimed to evaluate the effects of various fat and oil sources on performance, blood and immune variables of laying hens.

\section{Materials and Methods}

All procedures were approved by the Ethics Committee of Islamic Azad University, Arak Branch (Markazi, Iran) (No. IAAU, 1504). A total number of 140 Lohmann LSL Lite laying hens, 35 weeks old, with mean bodyweight (BW) of $1410 \pm 140 \mathrm{~g}$, were allocated to 35 cages with four birds per cage. To evaluate BW changes, laying hens were weighted at the start and the end of the trial. Birds were randomly divided into seven treatments and five replications with four laying hens per cage. A lighting programme (16 hours light / 8 hours dark) was used.

A corn-soybean meal basal diet was prepared as recommended by the Lohmann LSL-Lite catalogue (Lohmann LSL-Classic International 2011) by UFFDA software. The ingredients and composition of the basal diet are shown in Table 1. Dietary treatments consisted of i) basal diet or control (no oil or fat); ii) and iii) basal diets containing $1 \%$ and $3 \%$ SB oil; iv) and v) basal diets containing $1 \%$ and $3 \%$ kilka fish oil (KO); and vi) and vii) basal diets containing $1 \%$ and $3 \%$ (SFA). The experiment lasted for 84 days.

Egg production (EP), feed intake (FI) and egg weight (EW) were measured daily from each cage and FCR (FCR: $g$ feed: $g$ egg), and egg mass (EM) were calculated.

Laying hens (two birds per replicate) were administered with $0.02 \mathrm{~mL}$ of a $5 \%$ suspension of sheep red blood cells (SRBC) in $0.9 \%$ saline in days 21,49 and 77 . One week after the administration of SRBC, blood samples were collected by venipuncture and $3 \mathrm{~mL}$ whole blood was collected into tubes containing an anticoagulant. Each serum sample was inactivated at $56{ }^{\circ} \mathrm{C}$ for 30 minutes and then analysed for total antiSRBC antibodies (Delhanty \& Solomon, 1996). To evaluate the hemagglutination inhibition (HI) test, the OIE method was used on days 28,56 and 84 .

At days 28, 56 and 84 , blood samples were collected in non-heparinized tubes from two birds per cage ( $3 \mathrm{~mL}$ per bird) by puncturing the brachial vein. The samples were centrifuged at $2500 \times g$ for 10 min to obtain sera (Sigma 4-15 Lab Centrifuge, Germany). Individual serum samples were analysed to evaluate the malondialdehyde (MDA), triglycerides, cholesterol, HDL-C, LDL-C, albumin and VLDL-C. Variables were evaluated by spectrophotometer (Shimadzu UV-1700) using Pars Azmoon kit package (Pars Azmoon Co, Tehran, Iran).

The experiment was carried out as a completely randomized design with seven dietary treatments and five replications. Cage was regarded as an experimental unit for performance, while the data for individual birds were considered for blood biochemical parameters. The general linear model procedure of SAS (SAS institute 2001) was used to evaluate the data. The differences were evaluated with Duncan's multiple range test among group means $(P<0.05)$.

\section{Results}

When the data were evaluated, the results (Table 2) indicated that various fat sources did not have any significant effects on BW, EW and FI during the 12 weeks $(P>0.05)$. In other words, laying hens that received diets containing various levels of fat sources did not show significant differences compared with the control $(P>0.05)$. Moreover, the results indicated that higher levels of oil sources could not cause significant 
changes in EW and $\mathrm{FI}(P>0.05)$. EP and EM were increased significantly, and FCR was decreased in laying hens fed diets with KO and SFA at both levels $(1 \%$ and $3 \%)$ compared with the control group $(P<0.05)$. EP was significantly higher in laying hens treated with $3 \%$ SB compared with control $(P<0.05)$. There was no significant difference between 1\% SB and control groups in EP $(P>0.05)$. Laying hens in SB oil group did not show significant difference with laying hens in the control group for EM $(P>0.05)$. No significant differences were observed between higher and lower levels of KO and SFA for EP, EM and FCR $(P>0.05)$.

Table 1 Ingredients and composition of experimental diets used in laying hens fed diets with various fat sources

\begin{tabular}{|c|c|c|c|c|c|c|c|}
\hline Ingredient & Control & $1 \% \mathrm{SB}$ & $3 \% \mathrm{SB}$ & $1 \% \mathrm{KO}$ & $3 \% \mathrm{KO}$ & $1 \%$ SFA & $3 \%$ SFA \\
\hline Corn & 59.4 & 59.7 & 51.4 & 58.4 & 52.3 & 58.5 & 51.7 \\
\hline Soybean meal (44\%) & 29.4 & 28.2 & 29.8 & 29.4 & 30.2 & 29.3 & 29.9 \\
\hline Wheat bran & 0.00 & 0.00 & 4.80 & 0.00 & 3.50 & 0.00 & 4.40 \\
\hline KO (Pars kilka Company) & 0.00 & 0.00 & 0.00 & 1.00 & 3.00 & 0.00 & 0.00 \\
\hline SFA & 0.00 & 0.00 & 0.00 & 0.00 & 0.00 & 1.00 & 3.00 \\
\hline SB oil $\left(\right.$ Nastaran $\left.{ }^{\circledR}\right)$ & 0.00 & 1.00 & 3.00 & 0.00 & 0.00 & 0.00 & 0.00 \\
\hline DL-Methionine & 0.20 & 0.20 & 0.20 & 0.20 & 0.20 & 0.20 & 0.20 \\
\hline Salt & 0.30 & 0.30 & 0.34 & 0.30 & 0.34 & 0.30 & 0.34 \\
\hline Vitamin and premix & 0.25 & 0.25 & 0.25 & 0.25 & 0.25 & 0.25 & 0.25 \\
\hline Vitamin D3 & 0.10 & 0.10 & 0.10 & 0.10 & 0.10 & 0.10 & 0.10 \\
\hline L-Lysine & 0.20 & 0.20 & 0.00 & 0.20 & 0.00 & 0.20 & 0.00 \\
\hline Calcium & 8.84 & 8.84 & 8.84 & 8.84 & 8.84 & 8.83 & 8.84 \\
\hline Phosphate & 1.29 & 1.29 & 1.24 & 1.29 & 1.26 & 1.29 & 1.24 \\
\hline \multicolumn{8}{|l|}{ Nutrient composition (\%) } \\
\hline Metabolizable energy (kcal) & 2725 & 2725 & 2725 & 2725 & 2725 & 2725 & 2725 \\
\hline Crude protein & 18.5 & 18.5 & 18.5 & 18.5 & 18.5 & 18.5 & 18.5 \\
\hline Calcium & 3.73 & 3.73 & 3.73 & 3.73 & 3.73 & 3.73 & 3.73 \\
\hline Total phosphorus & 0.60 & 0.60 & 0.63 & 0.60 & 0.62 & 0.60 & 0.63 \\
\hline Av. Phosphorus & 0.38 & 0.38 & 0.38 & 0.38 & 0.38 & 0.38 & 0.38 \\
\hline Fibre & 3.46 & 3.46 & 3.81 & 3.46 & 3.72 & 3.45 & 3.80 \\
\hline Sodium & 0.16 & 0.16 & 0.16 & 0.16 & 0.16 & 0.16 & 0.16 \\
\hline Potassium & 0.77 & 0.77 & 0.81 & 0.77 & 0.80 & 0.77 & 0.81 \\
\hline Lysine & 0.79 & 0.79 & 0.79 & 0.80 & 0.80 & 0.80 & 0.79 \\
\hline Methionine & 0.50 & 0.50 & 0.50 & 0.50 & 0.50 & 0.50 & 0.50 \\
\hline Methionine + cysteine & 0.80 & 0.80 & 0.79 & 0.80 & 0.79 & 0.79 & 0.79 \\
\hline
\end{tabular}

Vitamin to improve mineral premix supplied (content per $\mathrm{kg}$ ): vitamin A: 1,800,000 IU; vitamin D3: 400,000 IU; vitamin E: 3,600 IU; vitamin K3: 400 mg; thiamine: 360 mg; riboflavin: 1,320 mg; niacin: 6,000 mg; vitamin B6: 600 mg; vitamin B5: 2,000; vitamin B12: 3 mg; folic acid: 200 mg; biotin: 20 mg; choline: 80 g; zinc: 17 g; iron: 10 g; copper: 2 g; manganese: $20 \mathrm{~g}$; selenium: $40 \mathrm{mg}$; iodine: $200 \mathrm{mg}$

SB: soybean; KO: kilka oil; SFA: soybean fatty acids

The current findings showed that the inclusion of KO and SFA fat sources could improve immunity variables in laying hens $(P<0.05)$ compared with the control group in terms of SRBC and $\mathrm{HI}($ Table 3$)$. Inclusion of SFA and KO at both levels could increase immune responses compared with the control group $(P<0.05)$. No significant differences were observed between the $1 \%$ SB group and the control group for SRBC and $\mathrm{HI}$ in 28 days and $\mathrm{HI}$ in 84 days $(P>0.05)$. Dietary supplementation of $3 \% \mathrm{SB}$ significantly increased the titre for $\mathrm{HI}$ in 28 and 84 days compared with the control group $(P<0.05)$. Higher and lower levels of fatty acids and KO oils did not show significant differences in immune response $(P>0.05)$, but better responses were observed in laying hens fed with $\mathrm{KO}$. 
Table 2 Effect of fat sources on productive performance of laying hens fed diets with various fat sources

\begin{tabular}{lcccccc}
\hline Groups & EP (\%) & EW (g) & EM (g/hen/day) & FI (g/hen/day) & FCR (g/g) & BW (g) \\
\hline Control & $85.0^{\mathrm{b}} \pm 5.60$ & $54.1 \pm 1.59$ & $51.2^{\mathrm{b}} \pm 1.59$ & $114.6 \pm 1.74$ & $2.2^{\mathrm{a}} \pm 0.09$ & $76.0 \pm 7.41$ \\
1\% SB & $89.4^{\mathrm{ab}} \pm 8.30$ & $55.1 \pm 1.29$ & $53.4^{\mathrm{b}} \pm 3.28$ & $114.6 \pm 1.75$ & $2.1^{\mathrm{a}} \pm 0.08$ & $65.0 \pm 3.51$ \\
3\% SB & $91.9^{\mathrm{a}} \pm 5.64$ & $52.3 \pm 1.59$ & $52.7^{\mathrm{b}} \pm 2.98$ & $115.1 \pm 2.02$ & $2.0^{\mathrm{b}} \pm 0.03$ & $60.0 \pm 6.12$ \\
1\% KO & $91.1^{\mathrm{a}} \pm 12.26$ & $53.2 \pm 1.59$ & $53.8^{\mathrm{a}} \pm 2.65$ & $114.6 \pm 1.61$ & $2.0^{\mathrm{b}} \pm 0.05$ & $69.0 \pm 14.75$ \\
3\% KO & $91.6^{\mathrm{a}} \pm 6.97$ & $52.2 \pm 1.59$ & $54.7^{\mathrm{a}} \pm 1.27$ & $114.0 \pm 1.60$ & $2.0^{\mathrm{b}} \pm 0.07$ & $68.0 \pm 5.70$ \\
1\% SFA & $92.3^{\mathrm{a}} \pm 6.50$ & $52.4 \pm 1.59$ & $54.9^{\mathrm{a}} \pm 1.96$ & $114.3 \pm 1.20$ & $2.0^{\mathrm{b}} \pm 0.05$ & $65.0 \pm 6.12$ \\
3\% SFA & $93.8^{\mathrm{a}} \pm 6.62$ & $52.4 \pm 1.59$ & $54.8^{\mathrm{a}} \pm 1.51$ & $114.4 \pm 0.90$ & $2.0^{\mathrm{b}} \pm 0.07$ & $67.0 \pm 10.37$ \\
SEM & 1.04 & 1.20 & 0.75 & 0.52 & 0.004 & 1.84 \\
P-values & 0.0001 & 0.076 & 0.0001 & 0.202 & 0.0001 & 0.359
\end{tabular}

Means $( \pm \mathrm{SD})$ within columns with different superscripts differ significantly $(P<0.05)$

SEM: Standard error of mean

EP: egg production; EW: egg weight; EM: egg mass; Fl: feed intake; FCR: feed conversion ratio; BW: body weight

SB: soybean; KO: kilka oil; SFA: soybean fatty acids

Table 3 Effect of various fat sources on responses of sheep red blood cells $\left(\log _{2}\right)$ and antibody titre against hemagglutination inhibition in laying hens fed diets with various fat sources

\begin{tabular}{lcccccc}
\hline Groups & SRBC28 & SRBC56 & SRBC84 & HI28 & HI56 & HI84 \\
\hline Control & $4.8^{\mathrm{c}} \pm 0.83$ & $5.6^{\mathrm{c}} \pm 1.14$ & $5.4^{\mathrm{c}} \pm 0.54$ & $7.8^{\mathrm{c}} \pm 1.090$ & $7.6^{\mathrm{c}} \pm 1.14$ & $7.4^{\mathrm{b}} \pm 1.51$ \\
1\% SB & $5.4^{\mathrm{c}} \pm 1.14$ & $6.4^{\mathrm{b}} \pm 0.89$ & $6.4^{\mathrm{b}} \pm 0.54$ & $7.8^{\mathrm{c}} \pm 0.83$ & $9.2^{\mathrm{b}} \pm 0.83$ & $8.2^{\mathrm{b}} \pm 1.48$ \\
3\% SB & $5.4^{\mathrm{c}} \pm 1.14$ & $6.0^{\mathrm{b}} \pm 1.58$ & $6.2^{\mathrm{b}} \pm 0.83$ & $9.6^{\mathrm{b}} \pm 0.54$ & $11.0^{\mathrm{a}} \pm 0.70$ & $11.2^{\mathrm{a}} \pm 0.83$ \\
1\% KO & $7.4^{\mathrm{a}} \pm 1.14$ & $9.0^{\mathrm{a}} \pm 0.70$ & $8.0^{\mathrm{a}} \pm 1.22$ & $9.6^{\mathrm{b}} \pm 0.54$ & $10.8^{\mathrm{a}} \pm 1.30$ & $10.0^{\mathrm{a}} \pm 1.00$ \\
3\% KO & $7.2^{\mathrm{a}} \pm 0.83$ & $8.6^{\mathrm{a}} \pm 0.54$ & $8.6^{\mathrm{a}} \pm 0.54$ & $10.8^{\mathrm{a}} \pm 0.83$ & $10.8^{\mathrm{a}} \pm 1.30$ & $11.2^{\mathrm{a}} \pm 0.83$ \\
1\% SFA & $6.4^{\mathrm{b}} \pm 0.54$ & $8.2^{\mathrm{a}} \pm 0.83$ & $7.0^{\mathrm{b}} \pm 1.41$ & $10.0^{\mathrm{a}} \pm 0.70$ & $9.4^{\mathrm{b}} \pm 2.40$ & $10.4^{\mathrm{a}} \pm 0.54$ \\
3\% SFA & $6.2^{\mathrm{b}} \pm 0.44$ & $8.2^{\mathrm{a}} \pm 0.83$ & $6.4^{\mathrm{b}} \pm 0.89$ & $10.2^{\mathrm{a}} \pm 0.44$ & $9.2^{\mathrm{b}} \pm 0.83$ & $11.6^{\mathrm{a}} \pm 0.54$ \\
SEM & 0.20 & 0.26 & 0.75 & 0.21 & 0.27 & 1.84 \\
P-values & 0.0006 & 0.0001 & 0.0001 & 0.002 & 0.002 & 0.001
\end{tabular}

Means $( \pm \mathrm{SD})$ within columns with different superscripts differ significantly $(P<0.05)$

SEM: Standard error of mean

SRBC: sheep red blood cells; HI: hemagglutination inhibition; SB: soybean; KO: kilka oil; SFA: soybean fatty acids

The current results showed that the fat sources did not have significant effects on the serum concentrations of LDL-C, VLDL and MDA $(P>0.05)$ (Table 4). The serum concentration of cholesterol was not influenced by the treatments in 56 and 84 days $(P>0.05)$, but was significantly higher in laying hens receiving diets containing $3 \%$ SB, KO and 1\% SFA $(P>0.05)$ compared with the control group at 28 days. The serum concentration of triglycerides was significantly lower in laying hens fed diets with various oil sources $(P<0.05)$. Significant differences were not observed between higher and lower levels of oils throughout the experiment for the serum concentration of triglycerides $(P<0.05)$. The data for the serum concentration of albumin were inconsistent. The serum concentration of albumin was significantly higher in laying hens that received diets containing $\mathrm{KO}$ and SFA and $1 \%$ soy-bean oil $(P<0.05)$. 
Table 4 Effect of various fat sources on blood biochemical variables $(\mathrm{mg} / \mathrm{dL})$ in laying hens fed diets with various fat sources

\begin{tabular}{|c|c|c|c|c|c|c|c|}
\hline Group & Triglycerides & Cholesterol & HDL-C & LDL-C & Albumin & VLDL & $M^{*}{ }^{*}$ \\
\hline & & & & 28 days & & & \\
\hline Control & $1895.0^{a} \pm 93.31$ & $146.1^{b} \pm 15.33$ & $66.8^{\mathrm{c}} \pm 5.97$ & $146.6 \pm 5.63$ & $1.6^{c} \pm 0.19$ & $299.9 \pm 38.69$ & $17.8 \pm 0.83$ \\
\hline $1 \% \mathrm{SB}$ & $1620.0^{b} \pm 127.60$ & $146.9^{b} \pm 21.30$ & $74.2^{b} \pm 6.02$ & $141.4 \pm 15.93$ & $1.5^{\mathrm{c}} \pm 0.12$ & $279.7 \pm 40.86$ & $16.0 \pm 1.58$ \\
\hline $3 \%$ SB & $1657.0^{b} \pm 149.60$ & $161.3^{\mathrm{a}} \pm 21.80$ & $88.4^{a} \pm 10.25$ & $150.7 \pm 14.51$ & $1.9^{\mathrm{a}} \pm 0.09$ & $290.4 \pm 40.50$ & $17.6 \pm 1.67$ \\
\hline $1 \% \mathrm{KO}$ & $1610.0^{\mathrm{b}} \pm 74.56$ & $161.8^{a} \pm 18.97$ & $72.1^{\mathrm{b}} \pm 8.50$ & $148.8 \pm 6.93$ & $1.7^{\mathrm{b}} \pm 0.15$ & $300.1 \pm 25.14$ & $17.2 \pm 1.92$ \\
\hline $3 \% \mathrm{KO}$ & $1637.0^{b} \pm 99.21$ & $186.2^{\mathrm{a}} \pm 23.60$ & $85.1^{\mathrm{a}} \pm 6.80$ & $155.8 \pm 9.72$ & $1.8^{\mathrm{b}} \pm 0.23$ & $298.9 \pm 37.20$ & $17.8 \pm 0.83$ \\
\hline $1 \%$ SFA & $1580.0^{c} \pm 96.67$ & $175.5^{\mathrm{a}} \pm 10.78$ & $72.0^{b} \pm 8.60$ & $152.0 \pm 9.82$ & $1.6^{\mathrm{c}} \pm 0.28$ & $280.8 \pm 45.80$ & $16.8 \pm 0.44$ \\
\hline $3 \%$ SFA & $1595.0^{c} \pm 79.74$ & $142.6^{\mathrm{b}} \pm 13.60$ & $82.5^{\mathrm{a}} \pm 3.70$ & $148.7 \pm 13.81$ & $1.7^{\mathrm{b}} \pm 0.13$ & $292.7 \pm 25.30$ & $16.8 \pm 1.09$ \\
\hline SEM & 30.68 & 5.40 & 1.96 & 7.12 & 0.21 & 9.03 & 0.225 \\
\hline \multirow[t]{2}{*}{$P$-values } & 0.0001 & 0.048 & 0.012 & 0.898 & 0.013 & 0.804 & 0.292 \\
\hline & & & & 56 days & & & \\
\hline Control & $1852.0^{a} \pm 80.491$ & $143.7 \pm 10.30$ & $39.9^{c} \pm 2.45$ & $142.8 \pm 3.22$ & $1.3^{\mathrm{d}} \pm 0.04$ & $335.3 \pm 29.68$ & $17.8 \pm 0.83$ \\
\hline $1 \% \mathrm{SB}$ & $1586.0^{b} \pm 43.68$ & $158.7 \pm 10.11$ & $58.7^{b} \pm 6.37$ & $145.5 \pm 6.05$ & $1.6^{c} \pm 0.11$ & $323.2 \pm 18.89$ & $16.0 \pm 1.58$ \\
\hline $3 \%$ SB & $1571.0^{b} \pm 93.68$ & $156.8 \pm 11.10$ & $72.0^{a} \pm 2.55$ & $148.6 \pm 5.11$ & $2.1^{\mathrm{a}} \pm 0.09$ & $341.2 \pm 20.49$ & $17.0 \pm 1.87$ \\
\hline $1 \% \mathrm{KO}$ & $1537.0^{\mathrm{b}} \pm 83.68$ & $149.6 \pm 16.47$ & $70.7^{a} \pm 2.24$ & $149.7 \pm 2.77$ & $1.5^{\mathrm{c}} \pm 0.12$ & $331.6 \pm 19.01$ & $16.0 \pm 1.58$ \\
\hline $3 \% \mathrm{KO}$ & $1653.0^{b} \pm 97.68$ & $157.7 \pm 19.70$ & $78.1^{a} \pm 6.43$ & $147.9 \pm 5.37$ & $2.0^{\mathrm{ab}} \pm 0.14$ & $278.9 \pm 52.91$ & $18.0 \pm 0.70$ \\
\hline $1 \%$ SFA & $1653.0^{b} \pm 99.68$ & $147.9 \pm 11.38$ & $65.3^{a} \pm 6.72$ & $144.2 \pm 6.18$ & $1.5^{\mathrm{c}} \pm 0.12$ & $317.4 \pm 19.21$ & $18.0 \pm 1.00$ \\
\hline $3 \%$ SFA & $1598.0^{b} \pm 80.68$ & $157.9 \pm 12.38$ & $65.3^{a} \pm 5.19$ & $149.8 \pm 8.95$ & $1.9^{b} \pm 0.11$ & $322.7 \pm 57.68$ & $17.2 \pm 1.64$ \\
\hline SEM & 57.28 & 3.46 & 2.79 & 1.40 & 0.056 & 6.85 & 0.292 \\
\hline \multirow[t]{2}{*}{$P$-values } & 0.0187 & 0.068 & 0.0001 & 0.151 & 0.0004 & 0.213 & 0.056 \\
\hline & & & & 84 days & & & \\
\hline Control & $1852.0^{\mathrm{a}} \pm 80.491$ & $141.7 \pm 15.30$ & $40.1^{d} \pm 1.37$ & $142.8 \pm 4.52$ & $1.2^{c} \pm 0.08$ & $351.2 \pm 13.60$ & $17.6 \pm 0.53$ \\
\hline $1 \% \mathrm{SB}$ & $1586.0^{b} \pm 52.61$ & $139.7 \pm 12.10$ & $60.1^{\mathrm{c}} \pm 2.45$ & $141.5 \pm 4.20$ & $1.4^{c} \pm 0.14$ & $371.2 \pm 15.60$ & $17.7 \pm 0.72$ \\
\hline $3 \%$ SB & $1575.0^{b} \pm 64.57$ & $145.7 \pm 9.41$ & $72.1^{b} \pm 3.41$ & $147.5 \pm 4.10$ & $1.5^{\mathrm{a}} \pm 0.08$ & $362.2 \pm 29.68$ & $17.4 \pm 0.65$ \\
\hline $1 \% \mathrm{KO}$ & $1696.0^{b} \pm 65.64$ & $158.2 \pm 15.61$ & $68.1^{b} \pm 2.45$ & $142.5 \pm 4.52$ & $1.4^{\mathrm{b}} \pm 0.12$ & $352.5 \pm 30.21$ & $17.3 \pm 1.04$ \\
\hline $3 \% \mathrm{KO}$ & $1536.0^{b} \pm 43.52$ & $156.7 \pm 12.30$ & $78.2^{\mathrm{a}} \pm 2.45$ & $141.2 \pm 5.65$ & $1.5^{\mathrm{a}} \pm 0.10$ & $361.3 \pm 22.45$ & $17.3 \pm 0.42$ \\
\hline $1 \%$ SFA & $1496.0^{\mathrm{b}} \pm 43.51$ & $149.0 \pm 12.56$ & $69.9^{b} \pm 2.45$ & $141.2 \pm 4.10$ & $1.4^{\mathrm{b}} \pm 0.04$ & $348.2 \pm 19.71$ & $17.8 \pm 0.61$ \\
\hline $3 \%$ SFA & $1516.0^{b} \pm 43.43$ & $151.8 \pm 7.65$ & $69.1^{b} \pm 2.45$ & $140.2 \pm 4.75$ & $1.5^{\mathrm{a}} \pm 0.04$ & $353.3 \pm 29.68$ & $16.9 \pm 1.83$ \\
\hline SEM & 62.250 & 4.21 & 3.10 & 1.30 & 0.051 & 5.81 & 0.35 \\
\hline$P$-values & 0.0231 & 0.057 & 0.024 & 0.712 & 0.023 & 0.351 & 0.562 \\
\hline
\end{tabular}

Means ( \pm SD) within columns with different superscripts differ significantly $(P<0.05)$

SEM: standard error of mean

${ }^{*} \mathrm{nmol} / \mathrm{mL}$

HDL-C: high density lipoprotein-C; LDL-C: low density lipoprotein-C; VLDL-C: very low density lipoprotein-C

SB: soybean; KO: kilka oil; SFA: soybean fatty acids

\section{Discussion}

The various fat sources did not have significant effects on BW, EW and FI for 12 weeks. However, the inclusion of KO and SFA increased EP and EM and decreased FCR compared with the control group. The inclusion of 3\% SB oil in the diet of laying hens significantly increased EP compared with control. The supplementation of $1 \%$ SB oil in the diet of laying hens did not improve their productive performance. The current findings for BW were similar to those reported by others (Baucells et al., 2000; Shafey et al., 2003). In contrast to the current observations, other studies did not report beneficial effects of oil sources on performance in laying hens (Baucells et al., 2000; Shafey et al., 2003; Guo et al., 2004; Cabrera et al., 2005). Mariod et al. (2015) showed that the inclusion of fish oil in the diet significantly increased egg size and egg production in laying hens. Increased EW in birds treated with KO and SFA oils could be attributed to the fatty 
acid content of the diet, which could influence egg weight (Vilchez et al., 1990; Vilchez et al., 1991). It could also be explained by physiological mechanisms. Fat sources decrease the rate of passage of the digesta and improve nutrient utilization (Baião \& Lara, 2005; Latshaw, 2008). It seems that SB oil at lower levels cannot improve nutrient utilization, which may be attributed to its structure. EM has a direct relation with EP. In other words, secretion of cholecystokinin and prolongation hormones in the gastrointestinal decreases transit time of feed and may help to improve feed efficiency (Hulan et al., 1984; Scheideier \& Baughman, 1989). It could be stated that KO and SFA help to secrete the cholecystokinin hormone and pancreatic enzymes into the small intestine to utilize feed in the gastrointestinal tract. Previous studies have shown that fat sources could improve feed intake in broiler chicks (Firman et al., 2010). The differences between the current findings and others could be attributed to strains of birds. Improved EP could be attributed to the degree of unsaturation because EP increases with increasing unsaturation. It was expected that higher levels of fish oil could improve performance efficiency, but this result was not observed.

The dietary supplementation of SFA and KO could improve immune responses compared with the control group. In addition, supplementation of $3 \%$ SB significantly increased titre for $\mathrm{HI}$ in 28 and 84 days compared with the control group. The best responses were observed in laying hens in KO group. Nutrition can have beneficial effects on immunity responses. Nutrition modulates and regulates immune processes, cellular activation and movement, anatomical development of lymphoid tissues, intracellular killing of pathogens, and synthesis of immunologically active substances (Butcher \& Miles, 2002). The various fat sources have beneficial effects on immune responses by influencing on antibody production. The supplementation of KO improved immune responses compared with control group. It has been reported that inclusion of fish oil in the diet increases the levels of eicosapentaenoic (EPA) and docosahexaenoic (DHA) acid (Valentini et al., 2017). Amino acids and EPA are both precursors for eicosanoids, which are known to have an essential role in inflammatory responses in human beings and animals such as poultry (Kim et al., 2007). Kew et al. (2003) showed that phagocytic activity and membrane fluidity of neutrophils and monocytes were adversely associated with the palmitic acid level and with the ratio of saturated to PUFA. Fatty acids modulate immunomodulatory molecules by mediating cellular communication, and elaborating second messenger and membrane fluidity (Watkins, 1991; Klasing, 1997). Fish oil reduces the levels of proinflammatory cytokines and anti-inflammatory cytokines (Chandrasekar \& Fernandes, 1994). Increased immunity by fish oil could be explained by increased T-cell proliferation and interleukin (Hayek et al., 1999). Fish oils reduce synthesis the prostaglandins in a number of tissues (Cunningham et al., 1997; Whigham et al., 1998). In summary, oils increase cellular immunity by modulation in phenotype and effector functions of $\mathrm{CD}^{+}$cells in both adaptive and innate immunity (Bassaganya-Riera et al., 2001). Thus, oils improve immune responses through these mechanisms. It seems that SB oil in lower levels cannot improve immune responses, which could be attributed to its structure, because KO could be more efficient in decreasing cytokines.

Regarding blood biochemical indices, LDL-C, VLDL and MDA were not influenced by fat sources, but the serum concentration of cholesterol was significantly higher in the fish oil group. The serum concentration of albumin was increased significantly in 3\% SB, KO and 3\% SFA. A correlation between MDA and lipids was observed, because MDA increases with levels of lipids. In contrast to the current findings, Zaki et al. (2018) reported that the use of SB oil sources decreased lipid oxidation in broiler meat. Lipoproteins transport cholesterol in the blood (Hermier \& Dillon, 1992). It has been reported that oils decrease the plasma concentration of cholesterol in laying hens (Mori et al., 1999). Decreased levels of lipids in groups treated with oils could be explained by reduction of synthesis rate of apoprotein B or the production of VLDL and triglycerides (Harris et al., 1984). Crespo \& Esteve-Garcia (2002; 2003) showed lower plasma VLDL and total cholesterol levels in birds treated with linseed oil and reported decreased cholesterol concentration by suppression of hepatic cholesterol production. This result was not found in the current study, which could be attributed to the levels that were used. Celebi \& Utlu (2006) reported a significant decrease in total cholesterol and VLDL-cholesterol in the blood serum of hens that received rations containing $4 \%$ linseed oil. Mighelenj et al. (2004) did not find significant changes in serum cholesterol of laying hens treated with canola seed and linseed at the rates of $2.5 \%, 5 \%$ and $7.5 \%$. The differences in fat sources could have beneficial effects on the results. In summary, if fat sources could influence lipid profile, MDA levels would be changed. In the current study, lipid profile and MDA were not affected by fat sources. The authors could not find any study that showed the effects of oils on levels of albumin.

\section{Conclusion}

In conclusion, dietary inclusion of KO and SFA at the levels of $1 \%$ and $3 \%$ could improve certain productive performance measurements, immunity variables, and some blood indices. The supplementation of diets with 3\% SB oil could improve productive performance and immune responses. Thus, inclusion of KO and SFA at lower levels and SB at higher levels could be useful in improving the immunity and performance 
in laying hens. KO and SFA at lower levels could thus be used instead of higher levels of SB. The use of KO and SFA could be recommended to improve the productive performance and immune responses in laying hens.

\section{Acknowledgements}

This work was supported by of Islamic Azad University, Arak Branch (Markazi, Iran).

\section{Authors' Contributions}

JF, HMY \& SK proposed project and wrote manuscript and SA conducted it.

\section{Conflict of Interest Declaration}

None.

\section{References}

Al-Khalifa, H., Givens, D., Rymer, C. \& Yaqoob, P., 2012. Effect of n-3 fatty acids on immune function in broiler chickens. Poult. Sci. 91, 74-88.

Alparslan, G. \& Ozdogan, M., 2006. The effects of diet containing fish oil on some blood parameters and the performance values of broilers and cost efficiency. Int. J. Poult. Sci. 5, 415-419.

Baião, N.C. \& Lara, L., 2005. Oil and fat in broiler nutrition. Rev. Bras. Ciênc. Avícola. 7(3), 129-141.

Bassaganya-Riera, J., Hontecillas, R., Zimmerman, D.R. \& Wannemuehler, M., 2001. Dietary conjugated linoleic acid modulates phenotype and effector functions of porcine CD8+ lymphocytes. J. Nutr. 131, 2370-2377.

Baucells, M., Crespo, N., Barroeta, A.C., Lopez-Ferrer, S. \& Grashorn, M.A., 2000. Incorporation of different polyunsaturated fatty acids into eggs. Poult. Sci. 79, 51-59.

Bou, R., Guardiola, F., Tres, A., Barroeta, A.C. \& Codony, R., 2004. Effect of dietary fish oil, alpha-tocopheryl acetate, and zinc supplementation on the composition and consumer acceptability of chicken meat. Poult. Sci. 83, 282-292.

Bozkurt, M., Küçükyilmaz, K., Çatli, A.U., Çınar, M., Bintas, E. \& Çöven, F., 2012. Performance, egg quality, and immune response of laying hens fed diets supplemented with mannan-oligosaccharide or an essential oil mixture under moderate and hot environmental conditions. Poult. Sci. 91, 1379-1386.

Butcher, G.D. \& Miles, R.D., 2002. Interrelationship of nutrition and immunity. University of Florida Cooperative Extension Service, Institute of Food and Agricultural Sciences, IFAS.

Cabrera, M.C., Saadoun, A., Grompone, A., Pagana, T., Sami, M., Olivero, R. \& del Puerto, M., 2005. Enriching the egg yolk in n-3 fatty acids by feeding hens with diets containing horse fat produced in Uruguay. Food Chem. 98, 767-773.

Celebi, S. \& Utlu, N., 2006. Influence of animal and vegetable oil in layer diets on performance and serum lipid profile. Int. J. Poult. Sci. 5, 370-373.

Chandrasekar, B. \& Fernandes, G., 1994. Decreased pro-inflammatory cytokines and increased antioxidant enzyme gene expression by $\omega-3$ lipids in murine lupus nephritis. Biochem. Biophys. Res. Comm. 200, 893-898.

Crespo, N. \& Esteve-Garcia, E., 2002. Nutrient and fatty acid deposition in broilers fed different dietary fatty acid profiles. Poult. Sci. 81, 1533-1542.

Crespo, N. \& Esteve-Garcia, E., 2003. Polyunsaturated fatty acids reduce insulin and very low density lipoprotein levels in broiler chickens. Poult. Sci. 82, 1134-1139.

Cunningham, D.C., Harrison, L.Y. \& Shultz, T.D., 1997. Proliferative responses of normal human mammary and MCF-7 breast cancer cell to linoleic acid, conjugated linoleic acid and eicosanoid synthesis inhibitors in culture. Anticancer Res. 17, 197-204.

Delhanty, J.J. \& Solomon, J.B., 1996. The nature of antibodies to goat erythrocytes in the developing chicken. Immunol. 11, 103-113.

de Oliveira, D., Baião, N.C., Vasconcelos Cançado, S., de Oliveira, B.L., Quintão Lana, A.M., Chaves, T. \& Figueiredo, D. 2011. Effects of the use of soybean oil and animal fat in the diet of laying hens on production performance and egg quality. Ciênc. agrotec. Lavras. 35, 995 -1001.

Ding, X., Yu, Y., Su, Z. \& Zhang, K., 2017. Effects of essential oils on performance, egg quality, nutrient digestibility and yolk fatty acid profile in laying hens. Anim. Nutr. 10, 127-131.

Eseceli, H. \& Kahraman, R., 2004. Effect of dietary supplementation of sunflower and fish oil with additive vitamin E or C on fatty acid composition of egg yolks and malondialdehyde levels in layer hens. Istanbul Üniv Vet Fak Derg. 30, 19-35.

Farhoomand, P. \& Chekani-Azar, S., 2009. Effects of graded levels of dietary fish oil on the yield and fatty acid composition of breast meat in broiler chickens. J. Appl. Poult. Res. 18, 508-513.

Firman, J.D., Leigh, H. \& Kamyab. A., 2010. Comparison of soybean oil with an animal/vegetable blend at four energy levels in broiler rations from hatch to market. Int. J. Poult. Sci. 9, 1027-1030.

Fritsche, K.L., Cassity, N.A. \& Huang, S.C., 1991. Effect of dietary fat source on antibody production and lymphocyte proliferation in chickens. Poult. Sci. 70, 611-617.

Guo, Y., Chen, S., Xia, Z. \& Yuan, J., 2004. Effects of different types of polyunsaturated fatty acids on immune function and $\mathrm{PGE}_{2}$ synthesis by peripheral blood leucocytes of laying hens. Anim. Feed Sci. Technol. 116, 249-257.

Harris, W.S., Connor, W.E., Inkeles, S.B. \& Illingworth, D.R., 1984. Dietary omega-3 fatty acids prevent carbohydrate induced hypertriglyceridemia. Metabolism 33, 1016-1019. 
Hayek, M.G., Han, S.N., Wu, D., Watkins, B.A., Meydani, M., Dorsey, J.L., Smith, D.E. \& Meydani, S.N., 1999. Dietary conjugated linoleic acid influences the immune response of young and old C57BL/6CrIBR mice. J. Nutr. 129, 32-38.

Hermier, D. \& Dillon, J., 1992. Characterization of dietary induced hypercholesterolemia in the chicken. Biochem. Biophys. Acta 11, 178-184.

Hulan, H., Proudfoot, F. \& Nash, D., 1984. The effects of different dietary fat sources on general performance and carcass fatty acid composition of broiler chickens. Poult. Sci. 63, 324-332.

Jalali, S.M.A., Rabiei, R. \& Kheiri, F., 2015. Effects of dietary soybean and sunflower oils with and without L-Carnitine supplementation on growth performance and blood biochemical parameters of broiler chicks. Arch. Anim. Breed. $58,387-394$.

Kew, S., Banerjee, T., Minihane, A.M., Finnegan, Y.E., Williams, C.M. \& Calder, P.C., 2003. Relation between the fatty acid composition of peripheral blood mononuclear cells and measures of immune cell function in healthy, freeliving subjects aged 25-72 years. Am. J. Clin. Nutr. 77, 1278-1286.

Kim, S.W., Mateo, R.D., Yin, Y.L. \& Wu, G., 2007. Functional amino acids and fatty acids for enhancing production performance of sows and piglets. Asian-Australas. J. Anim. Sci. 20, 295-306.

Klasing, K.C., 1997. Interaction between nutrition and infectious disease. In: Diseases of Poultry, B.W. Calnek, ed. Iowa State University Press, USA.

Larbier, M. \& Leclercq, B., 1994. Nutrition and Feeding of Poultry. 1st edition. Nottingham University Press, Nottingham, UK.

Latshaw, J.D., 2008. Daily energy intake of broiler chickens is altered by proximate nutrient content and form of the diet. Poult. Sci. 87, 89-95.

Lehninger, A.L., Nelson, D.L. \& Cox, M.M., 2002. Princípios Da Bioquímica. 4th edition. Editora Sarvier, São Paulo, $975 \mathrm{pp}$.

Lichovnikova, M., Šafaik, I., Lohnisky, A. \& Hampe, D., 2013. Effect of extruded full-fat soybeans on performance, amino acids digestibility, trypsin activity, and intestinal morphology in broilers. Czech. J. Anim. Sci. 58, 23-35.

Mariod, A.A., Mukhtar, M.A.E., Salih, M. \& Herwan, T., 2015. Effect of addition of fish oil on the performance parameters of laying hens and the fatty acid composition of their egg yolk. Am. J. Food. Sci. Health. 1, 38-42.

Mighelenj, A., Rahimi, S. \& Kamali, A., 2004. Effects of omega-3 fatty acid sources in laying hen diets on blood plasma cholesterol. 22nd World Poultry Congress, Istanbul, Turkey. 22 May, 2004.

Mori, A.V., Mendonc, C.X. \& Santos, C.O.F., 1999. Effect of dietary lipid lowering drugs upon plasma lipids and egg-yolk cholesterol levels of laying hens. J. Agri. Food. Sci. 47, 4731-4735.

Nobakht, A., Tabatbaei, S. \& Khodaei, S., 2011. Effects of different sources and levels of vegetable oils on performance, carcass traits and accumulation of vitamine in breast meat of broilers. Curr. Res. J. Biol. Sci. 3, 601-605.

Oliveira, D.D., Baiao, N.C., Cancado, S.V., Grimaldi, R., Souza, M.R., Lara, L.G.C. \& Lana, L.M., 2009. Effects of lipid sources in the diet of laying hens on the fatty acid profiles of egg yolks. Poult. Sci. 89, 2484-2490.

Pietras, M.P. \& Orczewska-Dudek, S., 2013. The effect of dietary Camelina sativa oil on quality of broiler chicken meat. Ann. Anim. Sci. 13, 869-882.

Pita, M.C., Piber Neto, G.E., Carvalho, P.R. \& Mendonca Junior, C.X., 2006. Efeito da suplementacao de linhaca, oleo de canola e vitamina $\mathrm{E}$ na dieta sobre as concentracoes de acidos graxos poliinsaturados em ovos de galinha. Arq. Bras. Med. Vet. Zootec. 58, 925-931.

Rowghani, E., Arab, M., Nazifi, S. \& Baktiari, Z., 2007. Effect of canola oil on cholesterol fatty acidcomposition on eggyolk of laying hens. Int. J. Poult. Sci. 6, 111-114.

Saki, A.A., Aliarabi, H., Cheraghi, P. \& Ahmadi, A., 2016. Effects of various levels of oxidized oil on performance, egg quality and some blood metabolites in laying hens. Poult. Sci. 4, 13-18.

Scheideier, S. \& Baughman, G., 1989. Feeding program and strain effect on roaster performance, heat stress mortality and carcass yield. Poult. Sci. 26, 130-150.

Schreiner, M., Hulan, H.W., Razzazi-Fazeli, E., Bohm, J. \& Iben, C., 2004. Feeding laying hens seal blubber oil, Effects on egg yolk incorporation, stereospecific distribution of omega-3 fatty acids, and sensory aspects. Poult. Sci. 83, 462-473.

Seidavi, A. \& Simoes, J., 2015. Evaluation of dietary fish oil plus green tea supplementation on the gizzard, ileum and cecum microflora in broiler chickens. Arch. Zootec. 64, 397-402.

Seidavi, A., Asadpour, L., Dadashbeiki, M. \& Payan-Carreira, R., 2014. Effects of dietary fish oil and green tea powder supplementation on broiler chickens' immunity. Acta. Scient. Vet. 42, 1-13.

Shafey, T.M., Dingle, J.G., McDonald, M.W. \& Kostner, K., 2003. Effect of type of grain and oil supplement on the performance, blood lipoproteins, egg cholesterol and fatty acids of laying hens. Int. J. Poult. Sci. 2, $200-206$.

Skrtic, Z., Kralik, G., Gajcevic, Z., Hanzek, D. \& Bogut, I., 2008. Effect of different source of oils on fatty acid profile and organoleptic traits of eggs. Acta. Agric. Slovenica. 2, 129-134.

Valentini, K.J., Austin Pickens, C., Wiesinger, J.A. \& Fenton, J.I., 2017. The effect of fish oil supplementation on brain DHA and EPA content and fatty acid profile in mice. Int. J. Food. Sci. Nutr. 69, 1-13.

Vilchez, C., Touchburn, S.P., Chavez, E.R. \& Chan, C.W., 1990. The Influence of corn oil and free fatty acids on the reproductive performance of Japanese quail (Coturnix coturnix japonica). Poult Sci, 69, 1533-1538.

Vilchez, C., Touchburn, S.P., Chavez, E.R. \& Chan, C.W., 1991. Effect of feeding palmitic, oleic, and linoleic acids to Japanese quail hens (Coturnix Coturnix japonica). 1. Reproductive performance and tissue fatty acids. Poult. Sci. 70, 2484-2493.

Watkins, B.A., 1991. Importance of essential fatty acids and their derivatives in poultry. J. Nutr. 121, 1475-1485. 
Whigham, L.D., Cook, E.B., Stahl, J.L., Saban, R., Pariza, M.W. \& Cook, M.E., 1998. Conjugated linoleic acid reduced antigen-induced prostaglandin E2 release from sensitized tracheas. Fed. Am. Soc. Exp. Biol. 12, A819.

Wu, G., Bryant, M.M., Voitle, R.A. \& Roland, D.A.S.R., 2005. Effect of dietary energy on performance and egg composition of Bovans White and Dekalb White hens during phase 1. Poult. Sci. 84, 1610-1615.

Yanovych, D., Czech, A. \& Zasadna, Z., 2013. The effect of dietary fish oil on the lipid and fatty acid composition and oxidative stability of goose leg muscles. Ann. Anim. Sci. 13, 155-165.

Zaki, E.F., El Faham, A.I. \& Nematallah G.M., 2018. Quality characteristics of chicken burger processed from broiler chicken fed on different types of vegetable oils and feed additives. Int. J. Health. Anim. Sci. Food. Safety 5, 1-11.

Zdunczyk, Z. \& Jankowski, J., 2013. Poultry meat as functional food, modification of the fatty acid profile - a review. Ann. Anim. Sci. 13, 463-480. 